\title{
Northwest African upwelling scenario
}

\section{Eberhard HAGEN*}

Baltic Sea Research Institute, Seestrasse 15, 18119 Warnemuende, Germany

Received 24 December 1999; revised 15 May 2000; accepted 16 May 2000

\begin{abstract}
Observations, hypotheses and derived scenarios are discussed for the Northwest-African coastal upwelling area. The process of coastal upwelling is considered to be composed of a climatic steady-state part and fluctuations acting on different spatial and temporal scales. Attention is focused on disturbances acting globally on the inter-annual time-scale. El Niño-like changes occur in the system of trade winds and modify the equatorial regime of currents as well as the coastal upwelling regimes on both flanks of the Inter-tropical Convergence Zone. There is an opposite thermal response in near-surface layers along the zonal coast in the Gulf of Guinea and along the meridional coast off NW-Africa. Off the continental slope of Senegal and Mauritania, the poleward undercurrent is linked with the system of eastward flowing equatorial undercurrents via the transport of South Atlantic Central Water (SACW) around the eastern flank of the Guinea Dome. The upwelling undercurrent partly feeds its SACW properties into the belt of coastal upwelling and contributes significantly to the biological productivity during 'normal' and 'abnormal' upwelling years. Future investigations should focus on changes in the time-scale of decades. () 2001 Ifremer/CNRS/IRD/Éditions scientifiques et médicales Elsevier SAS
\end{abstract}

Résumé - Upwelling au nord-ouest de l'Afrique. La zone d'upwelling située au nord-ouest des côtes africaines est étudiée dans le cadre d'une discussion portant sur les observations, les hypothèses et les scénarios qui en dérivent. Le phénomène d'upwelling côtier est considéré comme formé d'une composante climatique permanente et de fluctuations à différentes échelles d'espace et de temps. L'accent est mis sur les perturbations globales inter-annuelles. Des variations de type El Niño se produisent dans les alizés et modifient les courants équatoriaux et les upwellings côtiers des deux côtés de la convergence intertropicale. La réponse thermique diffère dans les couches proches de la surface, en raison de l'orientation de la côte, zonale dans le golfe de Guinée et méridienne au nord-ouest de l'Afrique. Devant la pente continentale du Sénégal et de la Mauritanie, le sous-courant orienté vers le pôle se rattache au système des sous-courants équatoriaux dirigés vers l'est par l'intermédiaire de l'Eau centrale de l'Atlantique Sud (SACW) qui contourne le flanc est du dôme de Guinée. Le sous-courant transfère partiellement les propriétés de l'eau SACW à l'upwelling côtier et contribue de manière significative à la productivité biologique pendant les années d'upwelling 'normal' et 'anormal'. Les travaux à venir devraient, entre autres, porter sur les variations à l'échelle des décennies. (C) 2001 Ifremer/CNRS/IRD/Éditions scientifiques et médicales Elsevier SAS

\section{Northwest Africa / northeast trade wind / coastal upwelling / poleward undercurrent / ENSO}

\section{Afrique occidentale / alizé du nord-est / upwelling côtier / sous-courant sud-nord / ENSO}

\footnotetext{
*Correspondence and reprints.

E-mail address: eberhard.hagen@io-warnemuende.de (E. HAGEN).
} 


\section{INTRODUCTION}

The coastal upwelling area off Northwest (NW) Africa is one of the four large systems of Eastern Boundary Currents (EBC) within the trade wind belts of the subtropics. Many aspects of this coastal upwelling have been verified by observations and modelling during the last 25 years. Important aspects of this EBC regime are recently reviewed by Barton (1998) on the base of observations along both the Northwest African and Iberian coast while Ajao and Houghton (1998) discussed features in the Gulf of Guinea. The objective of this paper is to draw attention to two additional points: the discussion of plausible hypotheses from the existing knowledge and the importance of inter-annual variability.

Continental shelves off NW-Africa vary in width with geographical location, but are typically of the order of $50-150 \mathrm{~km}$. The seabed gently slopes across the continental shelf from the coast to water depths of $200-300 \mathrm{~m}$. The shelf break zone with its steep continental slope extends over a distance of approximately $100 \mathrm{~km}$. Farther offshore, the deep ocean floor continues with water depths of 3000-4 000 m. Different chains of submarine sea mounts regionally disrupt the oceanic floor to form, for example, the Canary Islands and Madeira north of $25^{\circ} \mathrm{N}$. A topographic map with the seasonal migration of the northern boundary (NB) and the southern boundary (SB) of the northeast trade wind as well as the summer position of the southwest monsoon (NM) is shown in figure 1 .

Along the NW African coast, the meridional extension of the northeast trade winds covers a belt of approximately $1500 \mathrm{~km}$ between the southern and northern climatic boundaries. Between the boundaries, the southward and southwestward-directed Canary Current flows at the sea surface. It feeds its water into the North Equatorial Current at lower latitudes. The Canary Current is a relatively broad and weak wind-driven current at the same latitude as the Gulf Stream. It forms the eastern branch of the subtropical gyre rotating anticyclonically on the basin-scale. Its northern branch is given by the eastward flowing Azores Current west of $13^{\circ} \mathrm{W}$ at $34^{\circ} \mathrm{N}$ (Klein and Siedler, 1989). More detailed descriptions of the general circulation off Northwest Africa are given in Barton (1998) and Ajao and Houghton (1998).

To describe circulation structures in EBC regimes, a right-hand cartesian co-ordinate system $(x, y, z)$ is com-

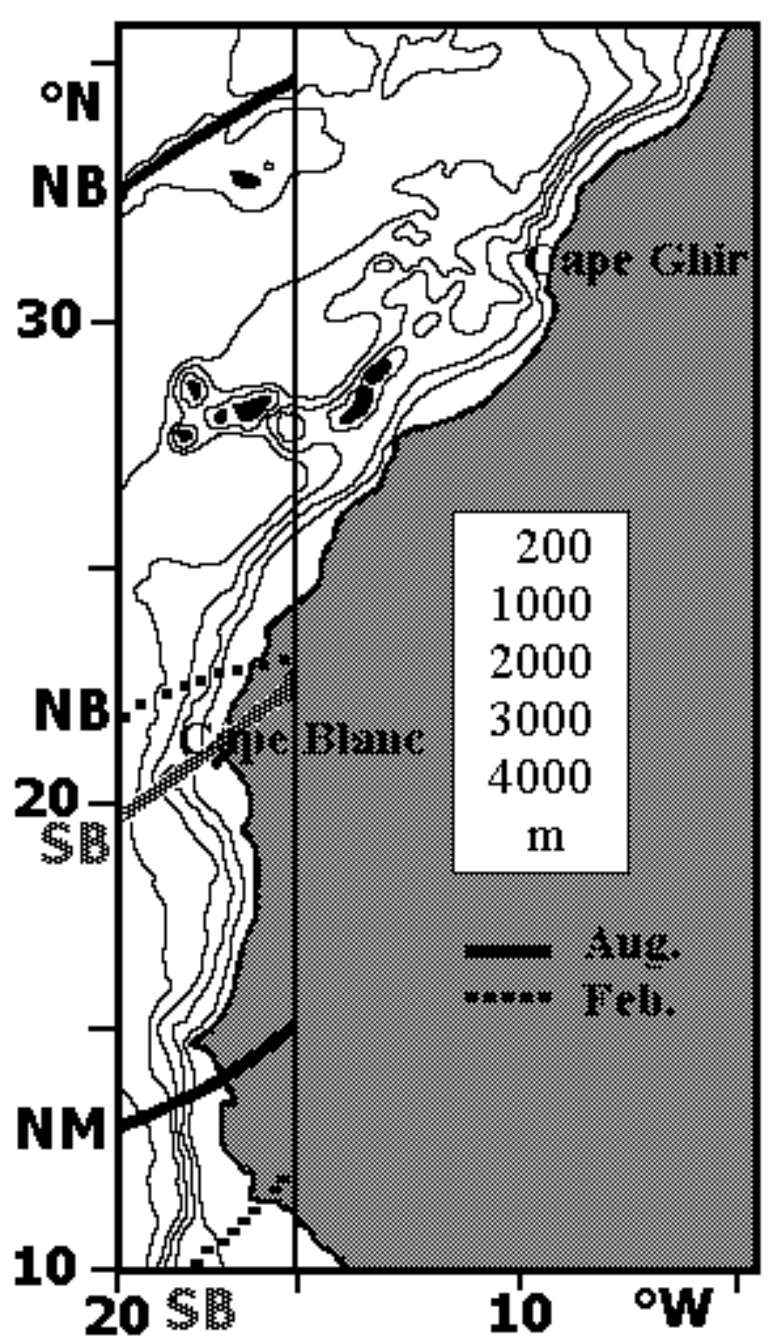

Figure 1. Rough shelf topography off Northwest Africa for selected depth contours $(\mathrm{m})$ with mean positions of the northern boundary (NB) and the southern boundary (SB) of the northeast trade wind system during August and February, with the summer position of the northern boundary of the southwest monsoon (NM) between $15^{\circ} \mathrm{W}$ and $20^{\circ} \mathrm{W}$ (Deutsches Hydrographisches Institut, 1956).

monly used. The $\mathrm{x}$-axis is positive onshore to the east and the shelf edge is located at $x=-L$. The y-axis aligns to the north and coincides with the coastline while the $\mathrm{z}$-axis is upward with the origin at the sea surface. The corresponding velocity components are $(u, v, w)$. Horizontal components of the wind stress are $\left(\tau^{x}, \tau^{y}\right)$ at the sea surface. The water depth $-H(x, y)$ is much larger than any anomalies in the sea level $\eta(x, y, t)$. The time is $(t)$ while the gravity acceleration is $g=9.8 \cdot \mathrm{m} \mathrm{s}^{-2}$. The pressure field is given by $\mathrm{p}(x, y, z, t)$ while the density is $\mathrm{Q}(x, y, z, t)$. 
Both are coupled via the hydrostatic approximation. Lateral gradients of the density are commonly much smaller than vertical gradients. The thickness of the well-stirred top layer is $-H_{\text {mix }}$ with the density $\varrho_{\mathrm{o}} \approx$ $10^{3} \mathrm{~kg} \cdot \mathrm{m}^{-3}$. The latitude $(\theta)$ determines the Coriolis frequency $f=2 \omega \sin (\theta)$ with the angular velocity of Earth's rotation $\omega=7.292 \cdot 10^{-5} \mathrm{rad} \cdot \mathrm{s}^{-1}$.

\section{STEADY-STATE}

\subsection{On-offshore circulation}

During the early 1970s, the steady-state concept of coastal upwelling was the dominant paradigm. The theoretical understanding was based on previously developed models such as those of Ekman (1905) and Hidaka (1954). The starting point was the modelling of a homogeneous ocean with a flat bottom topography, which is forced by uniform winds blowing along a straight coastline with a vertical 'continental slope'. Hidaka invoked lateral friction and showed that in this case the upwelling response was contained within a frictional sidewall layer of thickness analogous to the Ekman depth (Hidaka, 1954). A two-layer model was used by Yoshida (1955). The resulting upwelling belt is zonally confined to a relatively small coastal zone, which is determined by the internal radius of deformation $R=N H / f \approx 10-20 \mathrm{~km}$. The Väisälä frequency $N=\left[\left(g / \varrho_{0}\right) \cdot(\Delta \varrho / \Delta z)\right]^{1 / 2}$ reflects the vertical density difference $\left(\Delta \varrho / \varrho_{\mathrm{o}}\right) \approx 3 \cdot 10^{-3}$ between a light near-surface and a dense deep layer, both separated by the layer thickness $(\Delta z)$.

Off NW-Africa, the northeast trade wind blows with a climatic velocity around $6 \mathrm{~m} \cdot \mathrm{s}^{-1}$. Its equatorward component indicates the stress $\tau^{y} \approx-0.07 \mathrm{~N} \cdot \mathrm{m}^{-2}$. This component is responsible for an averaged Ekman-offshore transport per unit length:

$$
-E^{x}=\int_{-H m i x}^{0}-\mathrm{u}(z) d z \simeq-\frac{\tau^{y}}{\rho_{0} f}
$$

within the upper mixed layer $\left(-H_{\text {mix }}\right)$. Off Cape Blanc $\left(21^{\circ} \mathrm{N}\right)$, we obtain with $f=5 \cdot 10^{-5} \mathrm{~s}^{-1}$ the mean value of $-E^{\mathrm{x}} \sim 1.4 \mathrm{~m}^{2} \cdot \mathrm{s}^{-1}$. All offshore transports, which can be calculated easily from wind records via $\left(-\tau^{y}\right)$, agree well, both in magnitude and in variability, with those directly measured by current meters in the surface boundary layer (Lentz, 1992). This layer responds to the wind stress in a slab-like manner, but does not contain all of the winddriven transport. According to Lighthill (1969), the wind stress acts like a body force on superficial layers and covers layers deeper than the local mixing depth. Up to half of $\left(-E^{\mathrm{x}}\right)$ occurs in a transition layer involving the upper part of the seasonal pycnocline, which separates the top layer from nutrient-rich intermediate layers. The thickness of this transition layer is about the half of $\left(-H_{\text {mix }}\right)$. According to Smith (1995), several theoretical concepts probably underestimate $\left(-E^{x}\right)$ because they only attribute this transport to $\left(-H_{\text {mix }}\right)$. The thickness of $\left(-H_{\text {mix }}\right)$ generally depends on the wind history, the vertical current shear and the strength of underlying stratification, which is mainly determined by the seasonal pycnocline. The transport $\left(-E^{x}\right)$ disappears, or only occurs sporadically, in zones that lie outside of the trade wind belt. Its southern boundary roughly coincides with the climatic position of the northern part of the atmospheric Intertropical Convergence Zone (ITCZ). The climatic wind stress curl is negative above the Northeast Atlantic Ocean within a near-coastal zone with an offshore distance up to $300 \mathrm{~km}$, cf. corresponding maps in Isemer and Hasse (1987). Within the shelf zone off Cape Blanc with $-L \sim 50 \mathrm{~km}$, this curl permanently produces the Ekman pumping:

$$
\begin{array}{r}
w_{E} \approx\left(f \rho_{0}\right)^{-1} \partial \tau^{y} / \partial x \approx-\tau^{y} /\left(-L f \rho_{0}\right)=E^{x} / L \approx \\
3.10^{-5} \mathrm{~m} \cdot \mathrm{s}^{-1}>0
\end{array}
$$

at the base of the well-mixed top layer $\left(z \approx-H_{\text {mix }}\right)$. In the simplest case, there is a $\mathrm{x}$-z-plane along an infinite straight coastline with a vertical 'slope'. All alongshore motions may be geostrophically balanced by zonal pressure gradients $\left[v_{g}=(\partial p / \partial x) /(\varrho f)\right]$ while on-offshore currents are wind-driven $\left[u_{d}=\tau^{\mathrm{y}} / \varrho_{\mathrm{o}} f H_{\text {mix }}=E^{\mathrm{x}} / H_{\text {mix }}\right]$ in the top layer $\left(-H_{\text {mix }}\right)$ and vanish along the coastline. Due to the conservation of mass, we expect:

$$
\int_{-H}^{0} \mathrm{u}(z) d z=0
$$

in the near-coastal zone. This means that any offshore motions in the top layer must be compensated by onshore currents within deeper layers. Whether this deep onshore flow is balanced geostrophically by alongshore pressure gradients or by a bottom Ekman current is still an open question. Observations indicate both midwater- and bottom-trapped return flows off NW-Africa (Lentz, 1992; Tomczak and Godfrey, 1994). 

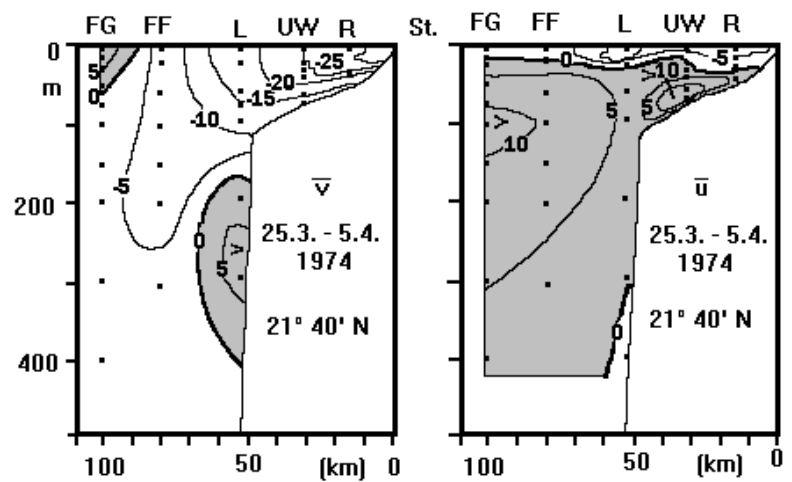

Figure 2. Averaged zonal structures of the onshore component $(u>0$ to the east) and the corresponding alongshore component ( $v>0$ to the north) as recorded by an array of current meters (dots) off Cape Blanc. Modified from Mittelstaedt et al. (1975).

We apply this simple concept to NW-Africa in the shelf zone off Cape Blanc. The climatic offshore transport was $-E^{x} \approx 1.4 \mathrm{~m}^{2} \cdot \mathrm{s}^{-1}$. This value corresponds to a vertically averaged offshore velocity of $-u=0.05 \mathrm{~m} \cdot \mathrm{s}^{-1}$ within $-H_{\text {mix }}=28 \mathrm{~m}$. Both values correspond well to averaged values from a current meter array, see figure 2. The time window of these measurements covers approximately two weeks. This is much too short for a serious discussion of climatic means. However, we may expect a sufficient signal-to-noise ratio within this 'cross-circulation' because the mooring array was deployed in the permanent upwelling zone off Cape Blanc. In other words, we like to accept that estimated means, plotted in figure 2, sufficiently describe the 'steady-state'. Under this assumption, the corresponding volume transport is approximately $-0.07 \mathrm{~Sv}$ $\left(1 \mathrm{~Sv}=10^{6} \mathrm{~m}^{3} \cdot \mathrm{s}^{-1}\right)$. Farther south at $11^{\circ} \mathrm{N}$, we estimate $-E^{x}=2.5 \mathrm{~m}^{2} \cdot \mathrm{s}^{-1}$ for the same wind stress. Considering upwelling along the shore, the shelf width $(-L)$ must be replaced by the deformation radius $(-R)$. According to Emery et al. (1984) the climatic first mode deformation radius is about $26 \mathrm{~km}$ at $21^{\circ} \mathrm{N}$ but $52 \mathrm{~km}$ at $11^{\circ} \mathrm{N}$. This means that the offshore extension of the upwelling belt decreases with increasing latitude and we obtain:

$$
\begin{array}{r}
w_{E}=E^{x} / R \approx \tau^{y} /\left(\rho_{0} N H\right) \approx 5.4 \cdot 10^{-5} \mathrm{~m} \cdot \mathrm{s}^{-1} \text { at } 21^{\circ} \mathrm{N}, \\
\operatorname{but} w_{E} \approx 4.8 \cdot 10^{-5} \mathrm{~m} \cdot \mathrm{s}^{-1} \text { at } 11^{\circ} \mathrm{N} .
\end{array}
$$

Both values apply for a base of $-H_{\text {mix }}=28 \mathrm{~m}$ and demonstrate that under conditions with a constant wind stress $\left(-\tau^{y}\right)$ the mean upwelling velocity $\left(w_{E}\right)$ decreases although the Ekman-offshore transport $\left(-E^{x}\right)$ increases with decreasing latitude. Consequently, a selected isopy- cnal surface at the base of a constant $-H_{\text {mix }}$ needs about six days to intersect the sea surface at $21^{\circ} \mathrm{N}$, but about seven days at $11^{\circ} \mathrm{N}$. Therefore, the 'upwelling turnover time' increases southward due to the higher stratification at $11^{\circ} \mathrm{N}$. These conditions are usually masked by processes which are associated with the meridional migration of the northeast trade wind during its seasonal cycle to produce the strongest upwelling within the permanent upwelling zone between $21^{\circ} \mathrm{N}$ and $23^{\circ} \mathrm{N}$. Over the shelf, the water circulation is mainly influenced by a sloping bottom topography, irregularities in the coastline, Earth's rotation, density stratification, and any offshore current regime involved in the anticyclonic gyre-scale circulation. Several conceptual models were developed hypothetically in order to describe related cells in the on-offshore circulation. An example is given in figure 3.

The cold upwelling belt is well separated from warm offshore waters by a frontal zone at the sea surface. Due to the permanent $\left(-E^{x}\right)$, this front acts like a barrier for any offshore motions. Therefore, a downwelling zone (convergence zone) should be expected along its onshore flank. Until now, there is no observational evidence from current measurements for such a downwelling strip. However, records of towed thermistor chains support this hypothesis by a clear downward displacement of isotherms (Keunecke and Tomczak, 1976; Tomczak, 1977). Consequently, the upper part of the water column is probably well ventilated at the onshore side of this frontal zone. Such intensified mixed regions of frontal zones are probably preferred feeding grounds for many fish species because of the accumulation of plankton, including fish larvae, due to the current convergence at the sea surface. In contrast, we may expect a weak secondary upwelling strip (divergence zone) along the offshore flank of this frontal zone. This secondary upwelling strip probably feeds water from above the pycnocline into superficial layers without any significant input of nutrients and without a significant biological response (Minas et al., 1982). With respect to further biological consequences of coastal upwelling we like to refer to previously reported results (Margalef, 1976; Cushing, 1982; Postel et al., 1995; John and Zelck, 1997).

\subsection{Southward coastal jet}

On the NW-African shelf, wind-driven currents are directed to the south and southwest within the cold 


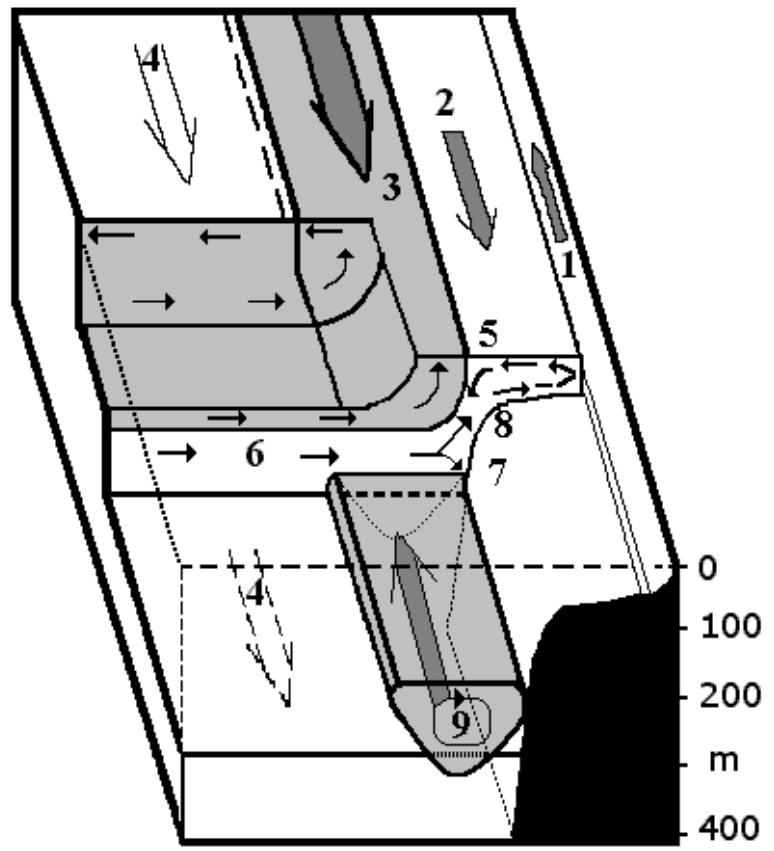

Figure 3. Some aspects of the two-dimensional steady-state current system according to Hagen (1981).

1) Zone of a weak near-shore countercurrent; 2) Primary upwelling zone with wind-induced southward currents between the main frontal zone (3) and the coastline; 3) Main frontal zone along the shelf edge as a result of pycnoclines rising to the sea surface, with embedded coastal jet; 4) Canary Current as eastern branch of the anticyclonic gyre circulation (dashed lines indicate weak countercurrents alternating temporally); 5) Wind-generated offshore current induces downwelling at the frontal barrier and intense mixing with vertical temperature inversions; 6) Onshore compensation current of intermediate layers is the main source of upwelling water; 7) Downward branch of (6), as part of the divergence zone of zonal currents off the continental slope; 8) Upward branch of (6) feeding upwelling water into (2); 9) Poleward flowing undercurrent with a thickness of several hundred meters.

upwelling belt. Above the shelf-break zone, the seasonal pycnocline intersects the sea surface to form a surface frontal zone following the course of the shelf edge (figure $3)$. Its offshore width varies between $10 \mathrm{~km}$ and $20 \mathrm{~km}$ and reflects the scale of the first mode baroclinic radius of deformation (Emery et al., 1984). This front vertically reaches down to $20-50 \mathrm{~m}$. Here an equatorward flowing coastal jet is embedded with core velocities between $-0.15 \mathrm{~m} \cdot \mathrm{s}^{-1}$ and $-0.25 \mathrm{~m} \cdot \mathrm{s}^{-1}$. Such a baroclinic coastal jet was explained originally in a two-layer model by Charney (1955). It involves a strong geostrophic component, which relates to sharpened zonal pressure gradients across the frontal zone. Positive anomalies of the sea level and vertically integrated 'dynamical depths' occur farther offshore while negative anomalies reflect the mass deficit maintained on the shelf.

\subsection{Poleward undercurrent}

Off the continental slope, zonal transects indicate that isopycnal surfaces frequently incline downward in layers beneath the seasonal pycnocline. This suggests the existence of a poleward-flowing undercurrent by the geostrophical adjustment between the mass-and-current field. It occurs in layers between 200 and $400 \mathrm{~m}$ depth off Cape Blanc $\left(21^{\circ} \mathrm{N}\right)$, see figure 2. Its upper part can partially inject non-regional water properties into the onshore transport to mix the upwelling water above the shelf. Hydrographic measurements identified the properties of the South Atlantic Central Water (SACW) for this undercurrent. When compared to the North Atlantic Central Water (NACW), which dominates farther offshore and at higher latitudes, the undercurrent transports SACW with relative minima in the salinity off the continental slope. Both water masses were well defined by Sverdrup et al. (1942) and later confirmed by Willenbrink (1982) on the basis of new data sets. Their quasi-linear temperaturesalinity relationships are plotted together with those of the underlying Antarctic Intermediate Water (AIW), North Atlantic Deep Water (NADW) and Mediterranean Water (MW) in figure 4. The data result from a meridional section compiled for stations off the continental slope by Barton (1973). According to Hughes and Barton (1974) and Barton (1989), the relative minimum in salinity slightly meanders vertically (probably also zonally) and roughly coincides with the potential density surface of $26.8 \mathrm{~kg} \cdot \mathrm{m}^{-3}$ up to a latitude of approximately $24^{\circ} \mathrm{N}$ (figure 5). Nutrient concentration is higher in the SACW than in the neighbouring NACW (Nehring et al., 1975; Minas et al., 1982). Consequently, the biological response is drastically accelerated in the upwelling water when the SACW of the upper part of the undercurrent feeds the onshore transport of intermediate layers to form mixed-water types on the shelf (Wolf and Kaiser, 1978).

At a latitude around $24^{\circ} \mathrm{N}$, where the relative salinity minimum disappears (figure 5), the southwestward flowing Canary Current departs from the continental slope and forms the beginning of the North Equatorial Current as the southern branch of the wind-driven subtropical gyre circulation. Southeast of the Canary Current, there is 


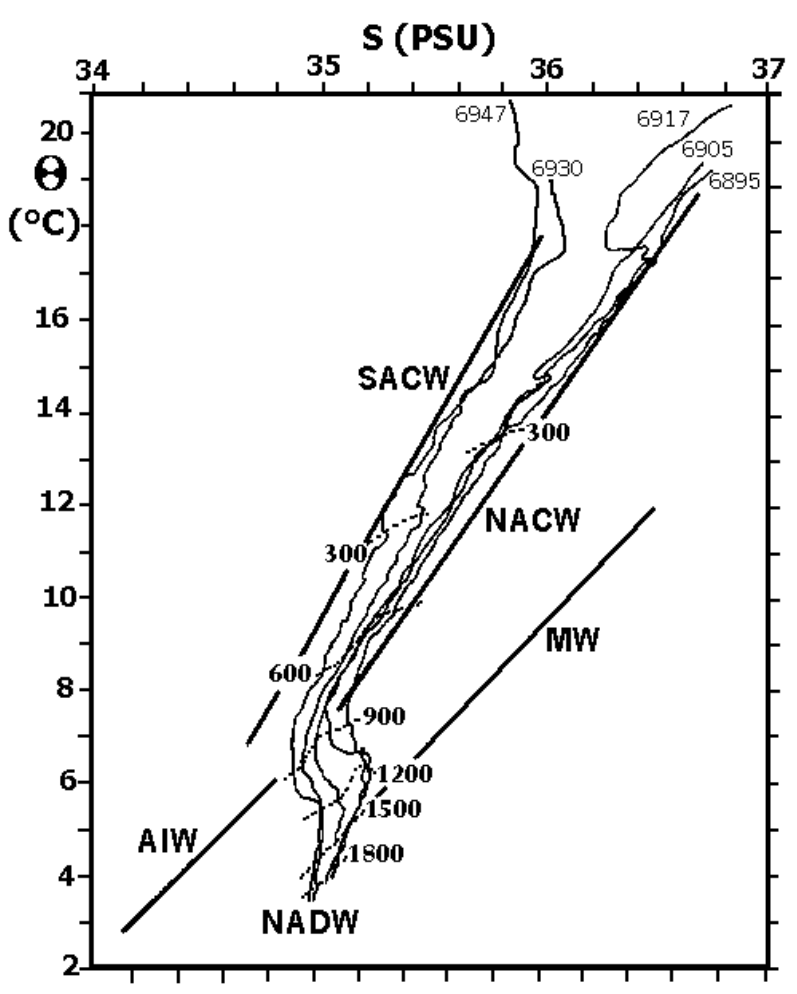

Figure 4. Potential temperature $\left({ }^{\circ} \mathrm{C}\right)$-salinity (PSU) curves for the outermost stations of the DISCOVERY survey carried out in April 1969 off Northwest Africa, modified from Barton (1973). Straight lines indicate involved water masses: South Atlantic Central Water (SACW), North Atlantic Central Water (NACW), Mediterranean Water (MW), Antarctic Intermediate Water (AIW, also abbreviated AAIW in literature), North Atlantic Deep Water (NADW). Dashed lines show associated pressure intervals (dbar).

a region that is not directly involved in the anticyclonic gyre circulation on basin-scale. It is mainly excluded from the seasonal ventilation (wintertime convection) of higher latitudes and named 'shadow zone' by Luyten et al. (1983). According to Zenk et al. (1991), the intermediate frontal zone (Cape Verde Frontal Zone) permanently separates the NACW in the northwest from the SACW in the southeast. Its orientation seems to coincide with the seasonally-averaged position of vanishing wind stress curl at the sea surface (Isemer and Hasse, 1987).

Intermediate layers of the entire 'shadow zone' are characterised by properties of the SACW, which are very constant not only in time but also in space. Due to mixing processes in the upper and deeper layers as well as through the frontal zone (diapycnal mixing), such constancy can only be explained by a permanent input of SACW into the

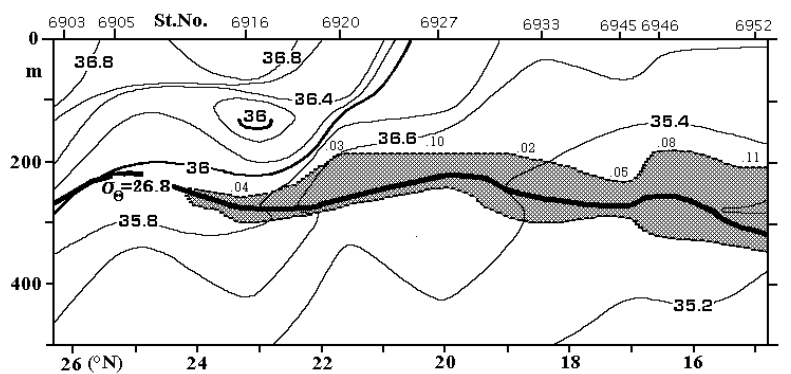

Figure 5. Longshore section of the salinity (PSU) carried out in April 1969 between Cape Bojador $\left(26^{\circ} \mathrm{N}\right)$ and Cape Vert $\left(15^{\circ} \mathrm{N}\right)$ modified from Hughes and Barton (1974). The dashed line indicates an intermediate salinity anomaly centred around the potential density surface of $26.8 \mathrm{~kg} \cdot \mathrm{m}^{-3}$ (hatched area); the intensity of the anomalies is indicated by the small numbers of practical salinity units.

area southeast of the Cape Verde islands. Possible candidates are the deep part of the North Equatorial Counter Current mainly flowing in superficial layers and the North Equatorial Under Current (NEUC) of intermediate layers between 150 and $500 \mathrm{~m}$ depth (Voituriez, 1981; Knoll et al, 1982; Tomczak, 1984). Both currents transport properties of the SACW eastward with a core velocity of up to $0.4 \mathrm{~m} \cdot \mathrm{s}^{-1}$. They frequently join each other and they flow parallel to the equator between $6^{\circ} \mathrm{N}$ and $8^{\circ} \mathrm{N}$ but west of approximately $23^{\circ} \mathrm{W}$ (Bubnov et al., 1979). The NEUC feeds the SACW into the 'shadow zone'. Here, the Guinea Dome is generated in near-surface layers, perhaps due to the joint influence of anomalies in the wind stress curl (southwest monsoon) and the continental slope on eastward flowing currents of deeper layers. Its centre lies around $12^{\circ} \mathrm{N}, 22^{\circ} \mathrm{W}$. The dome indicates an upward displacement of the seasonal pycnocline of typically 30 to $80 \mathrm{~m}$ over horizontal scales up to $1000 \mathrm{~km}$. Its rotational axis slightly shifts to the southwest with increasing depth. Demin et al. (1981) and Hagen and Schemainda (1984) concluded from diagnostic mass-field analysis and watermass analysis that the NEUC flows at its eastern end into this cyclonically rotating Guinea Dome. Along the eastern side of the dome, a current branch separates and transports SACW into the undercurrent off Cape Verde $\left(15^{\circ} \mathrm{N}\right)$ (figure 6). This current branch connects the system of equatorial undercurrents with that of the eastern boundary current system. Essential parts of this scenario were confirmed by Siedler et al. (1992).

From water-mass analysis, estimates of geostrophic currents, and time series data of moored current meters, the hypothesis arose during the mid-1980s that there could 


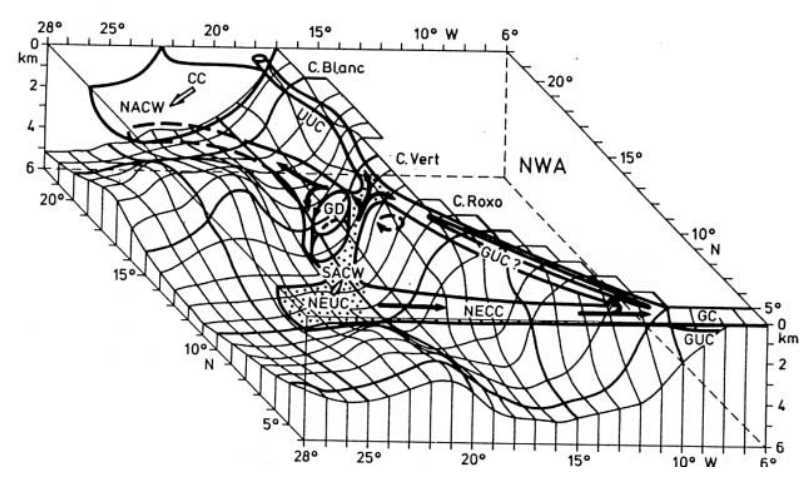

Figure 6. Cartoon of 'steady-state' branches of surface and superficial currents above the rough bottom topography in the southeastern North Atlantic Ocean from Hagen and Schemainda (1984); dots indicate the spreading of SACW from the NEUC into the GD and farther into the UUC; used abbreviations are: North Equatorial Undercurrent (NEUC), North Equatorial Counter Current (NECC), Guinea Current (GC), Guinea Undercurrent (GUC), Guinea Dome (GD), Upwelling Undercurrent (UUC), Canary Current (CC), North Atlantic Central Water (NACW), South Atlantic Central Water (SACW), North West Africa (NWA).

be a continuously flowing poleward undercurrent within layers of several hundreds of meters deep. Its core should transport characteristic water properties within intermediate layers from the region off the African continental slope towards that off the Iberian Peninsula (Meincke et al., 1975; Mittelstaedt, 1989; Zenk and Armi, 1990). Biological data support this idea (Brenning, 1985; Stöhr et al., 1997; John et al., 1998). Nevertheless, the question of how the Mediterranean Water outflow sinks through this poleward current is not yet answered. Unfortunately, climatic circulation schemata revealing the associated volume transport (Stramma, 1984) do not reveal this undercurrent because their data grid is much too coarse to resolve the scale of the internal deformation radius.

North of the northern boundary of the northeast trade wind system, the spreading of Mediterranean Water is closely connected with cores of intermediate undercurrents that flow poleward off the Portuguese continental slope during the whole year (Zenk, 1980). Upper parts of this undercurrent can, at least sometimes, intersect the sea surface when coastal upwelling is only weak or disappears in winter (Frouin et al., 1990). Based on relatively short-term current measurements, during a few days, a hint was given for such an undercurrent with core velocities of few $\mathrm{cm} \cdot \mathrm{s}^{-1}$ within layers between 500 and $700 \mathrm{~m}$ depth off the Moroccan continental slope by
Mittelstaedt (1989). Unpublished German current records in the Lanzarote-Africa channel suggest a strong northward flow at approximately $900 \mathrm{~m}$ depth for many months. An interesting question is: if the undercurrent is found around $300 \mathrm{~m}$ depth south of $24^{\circ} \mathrm{N}$, then why is it so much deeper further north? Obviously, there is a need for observation of this undercurrent transformation at these latitudes. Long-term records (September 1994-July 1998) of current measurements at the ESTOC-station (3 $600 \mathrm{~m}$ water depth, $29.17^{\circ} \mathrm{N}, 15.5^{\circ} \mathrm{W}$ ) suggest that such northward flowing currents involve a strong lowfrequency variability (weeks, months) without a clear 'climatic signal', Müller (personal communication, 1999). One may speculate that such variations along the rim of the basin-scale circulation influence the current regime off Morocco and could be the reason why the poleward undercurrent only sporadically crosses the Gulf of Cadiz. Such a situation is schematically indicated in figure 7. Among other things, the undercurrent core is indicated by relative minima in salinity. However, these minima are not caused by the influence of SACW. They probably result from eastward-spreading intermediate waters, which are mixed with properties of the NACW. The resulting mixed water type lies above the MW, which is characterised by elevated salinity but low levels of dissolved oxygen in layers around the horizon of $1200 \mathrm{~m}$. For instance, the bifurcation of undercurrents in the area south of Cape St. Vincent $\left(37^{\circ} \mathrm{N}\right)$ could be recently confirmed by drifting floats launched between 1000 and $2000 \mathrm{~m}$ by Bower (1996). The observational evidence for the 'continuity' of poleward flowing undercurrents across the Gulf of Cadiz still needs further field campaigns. However, there is no question that the undercurrent involves two 'dynamic aspects'. The first one corresponds to a 'steady-state' down-gradient flow, which is balanced by meridional pressure gradients off the continental slope on the basin-scale. Such gradients result from a superposition of wind and buoyancy forcing and are, for example, given by mean pressure levels of selected surfaces of the potential density in the nearcoastal zone (Lozier et al., 1995). These alongshore pressure gradients can be influenced by the topography due to meridional variations in the zonal slope of the continental shelf (Holloway et al., 1989). Another mechanism is based on regional dynamics. Its role is separately established in each upwelling region and strictly depends on seasonal forcing conditions off the Iberian Peninsula and off Northwest Africa. Below, the latter will be named 'upwelling undercurrent' (UUC). 


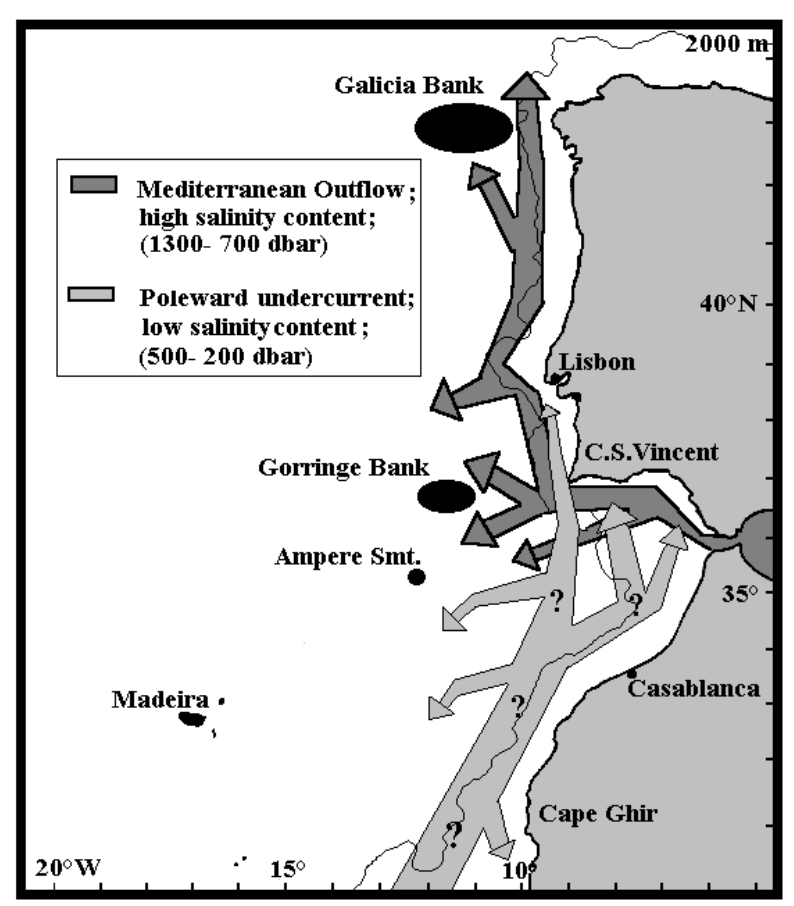

Figure 7. Hypothetical branches of sporadically occurring poleward flowing undercurrents starting in the upwelling area off Morocco and crossing the entrance of the Gulf of Cadiz (grey) above the Mediterranean outflow (dark grey) off the Portuguese west coast. Modified from Hagen et al. (1994).

\subsection{Variability}

\subsubsection{Decadal scale and El Niño-like changes}

Spatial and temporal variations are superimposed on the steady state of EBC regimes. The largest signal on inter-annual scales is that of the El Niño-Southern Oscillation (ENSO). The Southern Oscillation is the atmospheric component whilst the El Niño is the oceanic component of ENSO. Its temporal scale describes irregularly occurring fluctuations with quasi-periods between three and seven years. The origin of related anomalies lies in inter-annual disturbances of the equatorial current system in response to global changes in the trade-wind system of the Pacific Ocean. Associated patterns correlate over long distances (teleconnections) around the globe (Latif and Barnett, 1994). The ENSO-impact in the Atlantic-European region is, with respect to changed atmospheric circulation patterns and modified stormtracks, roughly half as strong as over the Pacific (May and Bengtsson, 1996). The tropical Pacific and the North Atlantic Ocean exhibit oscillatory-coupled ocean atmosphere modes, which correspond to decadal scale changes with a quasi-period of approximately 30 years (Grötzner et al., 1998). Via changed net heat fluxes from the ocean into the atmosphere, related anomalies are well manifested by changes in the core pressure of atmospheric action centres like the Icelandic Low, the Azores High and the Sahara Low (Ward and Hoskins, 1996). Therefore the intensity of Westerlies reflects these changes by decadal scale fluctuations of the North Atlantic Oscillation (NAO) (Rogers, 1984). The NAO results from differences in sea level air pressure between the Azores and Iceland. Subsequent fluctuations modify the intensity of the northeast trade wind system and cause inter-annually occurring changes in coastal upwelling off Northwest Africa. For instance, Sedykh (1978) reported a clear statistical relationship between inter-annually changed Ekman-offshore transports and fluctuating fish catches. This correlation was later confirmed by other authors in different coastal upwelling regions (Schwartzlose et al., 1999).

In general, the system of trade winds causes the accumulation of warm surface water in the equatorial West Atlantic. Here, the pycnocline declines in deeper layers and zonal pressure gradients are established within intermediate layers. They are mainly maintained by the zonal component of the southeast trade wind, because the meteorological equator (ITCZ) lies somewhat to the north of the geographical equator. These internal pressure gradients generate and maintain eastward flowing down-slope motions, which form the system of equatorial undercurrents in all equatorial oceans (Philander, 1980). According to Philander (1981), the relaxation of southeast trade winds disturbs this balance and a 'wave crest' of warm water starts to propagate eastward along the equator (equatorial Kelvin wave) while the westward flowing South Equatorial Current is weakened at the sea surface. Simultaneously, a reduction of zonal pressure gradients occurs in intermediate layers and the net transport of eastward flowing undercurrents is significantly reduced. The intermediate renewal of the SACW also must be reduced in the 'shadow zone' around the Guinea Dome while the inflow of equatorial surface water dominates with higher SSTs under comparable forcing conditions. Off the African coast, this 'warm water hill' theoretically splits up into two parts, which travel poleward (coastal Kelvin waves) along the continental slope. In their wake, both the SST and the thickness of the homogeneous top layer significantly 
increase. The increased hydrostatic pressure of the top layer pushes the seasonal pycnocline into greater depths. Consequently, winds favourable to upwelling are not able to 'pump' nutrient-rich waters into the local euphotic zone. Coastal upwelling relaxes with drastic consequences for the marine ecosystem involved. Therefore, globally occurring ENSO years should influence the upwelling regimes off Southwest and Northwest Africa via teleconnection. However, the upwelling regime of Northwest Africa is also controlled by very lowfrequency changes of the NAO. Here, the non-symmetric locations of the geographical and meteorological equator and the existence of a zonal coast in the Gulf of Guinea dramatically influence this scenario, although $\mathrm{El} \mathrm{Niño-}$ like fluctuations are well-documented (Servain et al., 1982). There is an unambiguous negative correlation between inter-annual anomalies of the SST (SSTA) along the northern part of the Gulf of Guinea and off NWAfrica (Cape Blanc) (Michelchen, 1989). This correlation suggests that years with pronounced wind-driven upwelling along the meridional coast of NW-Africa (negative SSTAs) coincide with relaxed upwelling along the zonal coast in the Gulf of Guinea (positive SSTAs). Here, the thermal structure at the coast mainly depends on both the intensity and the meridional extension of the Guinea Current (Colin, 1988). The increase of easterly trades in early summer in the Western Equatorial Atlantic is jointly responsible for the seasonal upwelling in the Gulf of Guinea via an equatorial Kelvin wave travelling eastward (O'Brien et al., 1978), although the wind-driven upwelling in the Gulf mainly results from the eastward component of the southwest monsoon. This monsoon occurs south of the ITCZ and must be considered as the northward extension of southeast trade winds due to the changed sign of the Coriolis force. Consequently, positive SSTAs in the Gulf of Guinea indicate a relaxed system of the southwest monsoon and the southeast trade wind during the upwelling season. Such a weak southeast trade wind also reduces coastal upwelling off Namibia and South Africa.

Michelchen (1989) showed that years with strong upwelling off NW-Africa statistically correspond to years with relaxed upwelling in the Gulf of Guinea and off SW-Africa and vice versa. Abnormal high SSTs in the Gulf of Guinea coincide with relaxed southeast trade winds. The relaxation of the southeast trade wind reduces westward winds balancing internal pressure gradients along the equator. Within the equatorial belt, decreased zonal pressure gradients reduce the transport of SACW in the system of eastward flowing equatorial undercurrents. As a consequence, transport is also reduced in both the Equatorial Undercurrent and the North Equatorial Undercurrent feeding SACW into the Guinea Current and the Guinea Dome. The input of SACW into the poleward undercurrent off Cape Verde $\left(15^{\circ} \mathrm{N}\right)$ is reduced with the consequence that the biological productivity decreases in coastal upwelling areas off Senegal and Mauritania, although there can be winds favourable to upwelling in the north of the ITCZ due to intensified northeast trade winds. During such years, the position of the ITCZ shows a southward displacement with respect to its climatic mean position and expands the Northwest African upwelling regime towards the equator. Opposite conditions occur for an abnormal northward displacement of the ITCZ in response to intensified southeast trade winds and relatively relaxed northeast trades.

Weak upwelling years are reported along the entire Northwest African coast. Sediment cores demonstrate a drastic reduction of the plankton production as evidenced by reduced sedimentation rates (Wefer and Fischer, 1993). According to Berger et al. (1989) the carbon $\left(\mathrm{CO}_{2}\right)$ flux from the ocean into the atmosphere must be strongly influenced due to increased SSTs. The response of upwelling regimes to the development of El Niño-like climatic changes and their role in climatic trends is still an open question although there is some general understanding from earlier efforts in other oceans (McCreary, 1976).

\subsubsection{Inter-annual and seasonal variations}

According to Michelchen (1981), coastal station measurements of sea-level air pressure and wind indicate that there are also quasi-periods between two and five years in the forcing. Associated amplitudes are approximately a factor three smaller than annual variations, and they decrease with decreasing latitude. A three-year period also occurs in climatic fields of the sea-level air pressure and of the SST (Hagen and Schmager, 1991). For instance, multi-year current time series are reported by Müller and Siedler (1992), whose measurements cover more than nine years for $33^{\circ} \mathrm{N}, 22^{\circ} \mathrm{W}$ (station Kiel-276). These records for the open Northeast Atlantic include an accumulation of kinetic energy for periods between 3 and 4 years and also between 50 and 200 days. A clear signal of the seasonal cycle could not be detected. This cycle only dominates in the oceanic coastal zone, especially in the belt of coastal upwelling. Here, coastal station records 
of air pressure and wind indicate a maximum in amplitudes of the seasonal cycle near $23^{\circ} \mathrm{N}$. This was also the critical latitude for the northward transport of SACW in the undercurrent and the departure of the Canary Current from the continental slope zone. In the south, coastal upwelling is observed between 23 and $21^{\circ} \mathrm{N}$ (Cape Blanc) during the whole year. This is well shown by remotely-sensed maps of the SST (Van Camp et al., 1991; Mittelstaedt, 1991; Nykjaer and Van Camp, 1994). The meridional migration of the main upwelling centre follows the annual course of the belt of northeast trade winds (Schemainda et al., 1975; Wooster et al., 1976; Speth and Köhne, 1983). Upwelling reaches its northernmost position in summer and its southern-most position in winter as shown in figures 1 and 8 .

Analytical and numerical circulation models provided insight into relevant dynamics contributing to threedimensional time-varying upwelling processes (McCreary, 1981; Suginohara, 1982; Philander and Yoon, 1982; Hsueh and Cushman-Roisin, 1983; Delecluse, 1983; Suginohara and Kitamura, 1984; Crepon et al., 1984). Their work can explain several, but certainly not all, characteristics and it is useful to present the following general results.

We consider a straight meridional coastline with its central part forced by the sudden onset of uniformly blowing winds in the direction of the equator. The northern and southern borders of the forcing area coincide with climatic boundaries of the trade wind belt. The trade wind is represented by a wind uniformly blowing from the north in a coastal belt of $300-500 \mathrm{~km}$. Elsewhere the wind stress vanishes. Associated 'equilibrium conditions' are of particular interest. First, the circulation is two-dimensional as described above for steady-state conditions. Any spatial variations are confined to a plane perpendicular to the coast. The salient features of the forcing region are given by an acceleration of the coastal jet in superficial layers. The zonal width of this coastal jet is confined to the scale of the internal radius of deformation. At the equatorward edge of the forcing area, non-dispersive Kelvin waves are excited to fulfil the boundary conditions and to establish alongshore pressure gradients balancing the wind forcing. Such waves travel with the coast on their right side and need several days to pass the forcing area. Their amplitude is greatest at the coastline and decays exponentially away from it. The Coriolis force balances the pressure gradient force due to the slope in sea level anomaly at each point at any time.
1972 - 1980

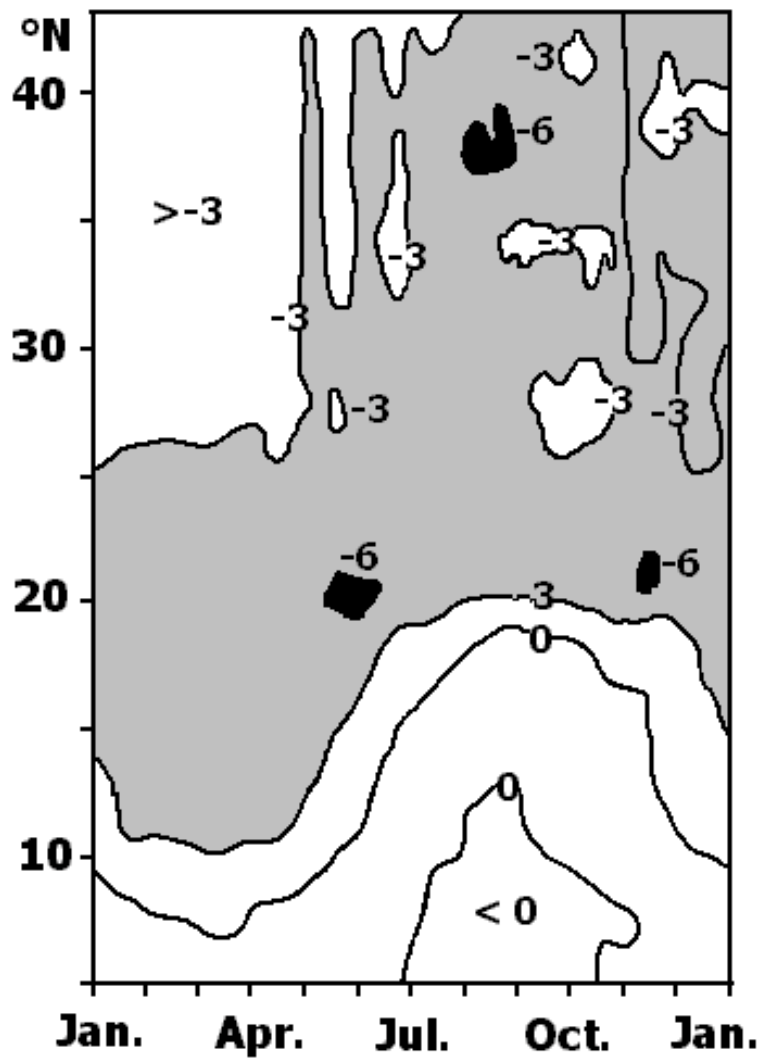

Figure 8. Monthly-averaged differences of the sea surface temperature $(\mathrm{K})$ between the coastal zone and the open North Atlantic Ocean for 1972-1980 redrawn from Speth and Köhne (1983); values below $-3 \mathrm{~K}$ are hatched and those below $-6 \mathrm{~K}$ are dark. Permanent coastal upwelling with differences larger than $-3 \mathrm{~K}$ occurs between $25^{\circ} \mathrm{N}$ and $20^{\circ} \mathrm{N}$; the northernmost upwelling dominates in the late summer until early autumn off the Iberian peninsula while the southernmost extension of upwelling is observed in late winter and spring at approximately $11^{\circ} \mathrm{N}$.

This type of wave is not associated with any off-onshore flow. After the passage of the Kelvin wave through the northern wind boundary, the coastal jet is arrested until friction balances the input of momentum from the wind and equilibrium conditions exist between forcing and oceanic response. Thereafter, the coastal jet is 'steady' and its divergence feeds the Ekman offshore drift to reduce the mass deficit in the coastal zone. Consequently, the upwelling relaxes and finally stops for a certain period of time. Hence, Kelvin waves are seen to modify the coastal flow regime dramatically. Their 
vertical structure is composed of a barotropic part and several baroclinic modes. The barotropic signal propagates much faster (days) than those of any baroclinic mode (months). The associated coastal jet is vertically confined to superficial layers of several tens of meters deep because the body force of the wind stress disappears in deeper layers. The arrival of the barotropic Kelvin wave at the poleward border of the forcing area establishes meridional pressure gradients balancing the upwelling undercurrent (UUC), which flows in a direction opposite to that of the coastal jet. Subsequent baroclinic waves modify the vertical structure of the coastal jet and that of the UUC because the vertical structure of such baroclinic waves differs from that of the relatively shallow coastal jet. Equilibrium can only occur after the passage of all baroclinic wave contributions (modes) through the forcing area. The higher the mode, the lower is the propagation speed. Friction processes may dampen very slowly travelling higher modes so that only several baroclinic wave-modes really contribute to the establishment of an 'equilibrium'. A compact analytical formulation of this scenario is for instance provided by Fennel (1992), while some observational evidence is documented by Siedler and Finke (1993).

The duration of the residence time of all relevant baroclinic modes indicates that the 'equilibrium' can only be expected for times of the order of the seasonal cycle. Therefore, $\beta$-plane dynamics enter the flow field. Seasonally forced Rossby waves start along the coastline. After a critical period of several months, the trapping scale of the baroclinic radius of deformation for both the equatorward coastal jet and the poleward UUC will be replaced by the distance that Rossby waves travel to the West. In the coastal zone, a complex system of northward and southward currents appears with opposite signs in nearsurface and intermediate layers. Currents of alternating signs flow parallel to meridional wave crests. Their meridional extension roughly corresponds to that of the forcing area. At a fixed latitude of the forcing belt, planetary Rossby waves radiate into the open Northeast Atlantic Ocean and 'export' associated upwelling properties (Rossby dispersion). Both the coastal jet and the UUC could be seen as a permanent ingredient of seasonally forced Rossby waves.

Bray (1982) reported some observational evidence for baroclinic Rossby waves to the north of $42^{\circ} \mathrm{N}$ while the offshore displacement of the poleward flowing undercurrent was indirectly discussed by Hagen and Schemainda
(1987) referring to two subsequent zonal transects sampled in April 1983 and February 1984 at $21^{\circ} \mathrm{N}$ off Cape Blanc. They identified three geostrophic cores of northward currents transporting relatively high concentrations of South Atlantic Central Water (SACW) in layers between 200 and $500 \mathrm{~m}$ depth. The associated zonal wavelength was around $260 \mathrm{~km}$. One of the transects is redrawn in figure 9. In order to obtain information about the associated westward propagation, a hydrographic data set was compiled for three zonal sections off Nouadhibou $\left(21^{\circ} \mathrm{N}\right)$, Noakchott $\left(18^{\circ} \mathrm{N}\right)$, and Dakar $\left(15^{\circ} \mathrm{N}\right)$ by Hagen and Schemainda (1989). These sections extended to an offshore distance of around $300 \mathrm{~km}$. The measurements were carried out between 1971 and 1974, always at the same stations. With the assumption that the seasonal cycle is the energetically most pronounced signal, and mixing processes mainly occur on density surfaces, they reconstructed the annual course for the concentration of the SACW within the layer enclosed by the density surfaces of $26.4 \mathrm{~kg} \cdot \mathrm{m}^{-3}$ and $26.7 \mathrm{~kg} \cdot \mathrm{m}^{-3}$. The westward propagation was detected by monthly displacements of peak values in the SACW concentration. The values obtained sufficiently confirmed the theoretically expected value of approximately $-0.01 \mathrm{~m} \cdot \mathrm{s}^{-1}$ (Krauss and Wübber, 1982; Lippert and Käse, 1985). Such westward radiation of seasonally forced Rossby waves should attack/disturb any meridionally flowing branches of the 'steady-state circulation' in the entire Northeast Atlantic Ocean, at least within the belt of the northeast trade wind, although Klein and Siedler (1989) reported three south-southwestward flowing branches of the permanently existing Azores Current south of $30^{\circ} \mathrm{N}$.

\subsubsection{Multi-day fluctuations}

Three-dimensional upwelling scenarios were also developed for relatively short fluctuations with periods from a few weeks to several days for typical hydrographic conditions (Mysak, 1980). The continental shelf acts as a wave-guide for any subinertial waves with periods longer than the inertial period $\left(T_{\mathrm{i}} \approx 1.5\right.$ day at $\left.21^{\circ} \mathrm{N}\right)$. It is well known that the energy accumulates where the group velocity disappears in the dispersion relationship of such waves. Stratification and shelf geometry control baroclinic Rossby waves, which are topographically trapped. In the vorticity balance, the variation of the Coriolis frequency with the latitude $(\beta=\mathrm{d} f / \mathrm{d} y)$ is 'replaced' by the topographic beta effect $\beta_{T}=(f / H) \cdot(\mathrm{d} H / \mathrm{d} y)$. Their signals propagate poleward with the coastline on the right hand 


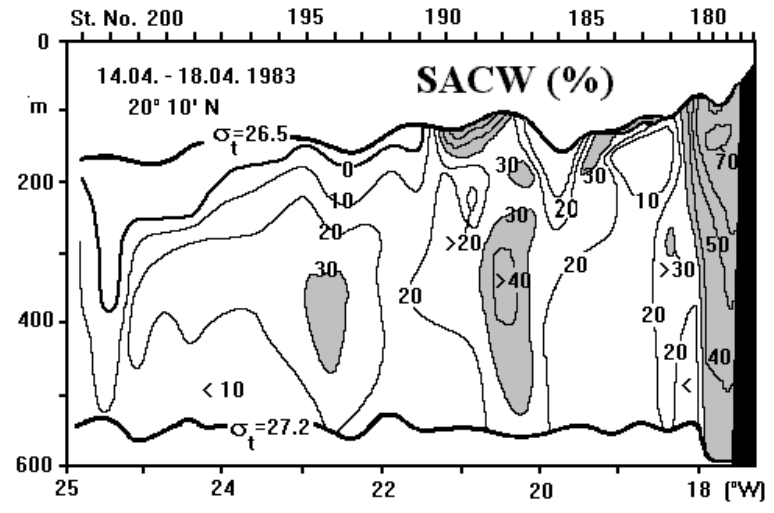

Figure 9. Percentages of South Atlantic Central Water (30\% of SACW corresponds to $70 \%$ of NACW) between selected isopycnals along a zonal transect off Cape Blanc $\left(20^{\circ} 10^{\prime} \mathrm{N}\right.$, April 1983) (Hagen and Schemainda, 1987). The upper abscissa indicates running station numbers with the spacing of $10 \mathrm{n} . \mathrm{m}$. and $20 \mathrm{n} . \mathrm{m}$. while the longitude is given separately. The core of the poleward flowing undercurrent transports more than $70 \% \mathrm{SACW}$ at approximately $150 \mathrm{~m}$ depth along $18^{\circ} \mathrm{W}$ off the continental slope; the second core coincides with SACW $>40 \%$ at $350 \mathrm{~m}$ near $20.5^{\circ} \mathrm{W}$; the third core coincides with $\mathrm{SACW}>30 \%$ at $400 \mathrm{~m}$ farther offshore, at approximately $23^{\circ} \mathrm{W}$. The offshore separation of all three cores is $260 \mathrm{~km}$. With respect to the hypothesis of seasonally triggered Rossby dispersion, the first core represents the actual undercurrent (UUC) while the second core corresponds to that of the last year, and so on.

side. Until now, there is only poor observational evidence for this kind of waves off NW-Africa. This aspect needs further experimental efforts in the future.

Linear models with slight friction terms described upwelling as being simply a raising or lowering of the pycnocline along the coast, without any changes in the water properties at the sea surface (Gill and Clarke, 1974). Related variations in sea level anomalies $\eta(x, y, t)$ indicate changes between $0.02 \mathrm{~m}$ and $0.15 \mathrm{~m}$ with periods in the range of 2-7 days. Within the nearly homogeneous cold water belt, they propagate polewards with properties of barotropic continental shelf waves (CSWs) and show a strong correspondence to changes in the alongshore wind component. Related dynamics are explained by Huthnance (1975). CSWs involve characteristic periods between 2.5 and 6 days, which are determined by the first three on-offshore modes. Associated sea level anomalies propagate with velocities of 180,70 , and $30 \mathrm{~km}$ per day at $21^{\circ} \mathrm{N}$ (Hagen, 1981). From the cross-correlation between meridionally separated sea-level records near Saint Louis $\left(16^{\circ} \mathrm{N}\right)$, Catewicz and Hagen (1989) reported a northward propagation of $155 \mathrm{~km}$ per day for the period of approximately three days. The corresponding dispersion relationship suggests a meridional wave-length around $300 \mathrm{~km}$ for first mode CSWs. The modification of dispersion curves by continuous stratification, without a strong pycnocline over the shelf, has been investigated by Huthnance (1978). It follows that topographically trapped baroclinic fluctuations are important in the shelf-edge zone. Here, the linear theory of CSWs breaks down. Mode-mode interactions favour the establishment of meso-scale eddy-like features although the daily variability of $-\tau^{y}(x, y, t)$ also influences the current regime of superficial layers above the shelf-edge zone (Barton et al., 1977; Brink, 1983).

\subsubsection{Eddy-like features}

More sophisticated circulation models show that friction processes play a crucial role, not only in the well wind-stirred top layer but also in the pycnocline and in the bottom boundary layer (see Csanady, 1971; O'Brien and Hurlburt, 1972; Blumsack, 1972; Garvine, 1973; Tomczak and Käse, 1974; Bleck, 1978; McCreary, 1981 and many other investigations quoted herein). Released mixing processes control the formation and/or maintenance of frontal zones and released eddy-like features. The importance of friction increases with decreasing spatial scale. Consequently, frontal meanders, filaments, and eddies need non-linear physics for an adequate description. Numerical circulation models regard nonlinear dynamics. They use digitised bottom topography and coastal boundaries with observed background stratification and observed wind. Resulting simulations provided conceptual schemata for circulation patterns motivating directed field campaigns. It became evident that coastal upwelling relates to different physical mechanisms acting on different space and time scales. Consequently, the belt of upwelling water must be considered as the result of different processes acting in concert and producing a stochastic component not only in space but also in time. Furthermore, it became increasingly evident that undercurrents also contribute to the 'biological intensity' of upwelling processes.

Deep canyons frequently occur in the shelf topography off Mauritania. In the deep mouth of such a canyon, the alongshore pressure gradients can be drastically disturbed due to mechanisms mentioned above. The width of the canyon mouth is frequently larger than the internal deformation radius and on-offshore currents are highly geostrophic. Opposite conditions dominate in the vicin- 
ity of its head on the shelf. Here, friction processes determine the momentum balance. Such canyons act like a natural drainage. They convey properties of the SACW, which are transported by the UUC off the continental slope, into the shelf zone to form intense upwelling patches. A 'plume' of cold water, which is topographically fixed, indicates the canyon head by an enrichment of nutrient and plankton within near-surface layers (Postel and Zahn, 1987). Resulting mixed waters frequently produce an elliptic upwelling plume. Its main axis follows pronounced wind-driven currents. This means that intense upwelling patterns can be locally fixed but their intensity is 'hydraulically controlled' by the undercurrent flowing off the canyon mouth. Similar conditions occur in topographically controlled upwelling filaments above the submarine plateau off Cape Ghir $\left(31^{\circ} \mathrm{N}\right)$ (Hagen et al., 1996). According to Holloway et al. (1989), there is a tendency for a negative relative vorticity to correlate with topographic elevations although one anticipates that the stratification shields much of the water column from the influence of topography. However, the impact of the poleward flowing undercurrent on the generation/ maintenance of filaments is still an open question.

Similar phenomena result from separated meanders of the frontal zone due to the dynamics discussed above. Current instabilities produce rotating upwelling lenses to form eddy-like structures with their own dynamics with time-scales of several days. Such eddy-like features were also detected off Cape Blanc $\left(21^{\circ} \mathrm{N}\right)$. They travel in the cold upwelling belt in the direction of surface currents and frequently show a cyclonic rotation. Their diameter is 15-20 km (Hagen and Kaiser, 1976; Mittelstaedt, 1976; Hagen, 1977; Mittelstaedt and Haman, 1981). Such upwelling patches trap temperature-salinity properties, which result from mixing processes between freshly upwelled water and heated surface water. Above the shelf, mixed water types are well ventilated and favour the development of a rich production of plankton in drifting upwelling plumes (Gillbricht, 1977).

\section{CONCLUSION}

Regions with coastal upwelling provide a natural laboratory to study fluxes of energy and matter in marine ecosystems. Most related field campaigns involved not only meteorological and hydrographic observations but also chemical, biological, and geological measurements. Therefore, the study of coastal upwelling processes regionally requires the participation of all marine disciplines to elucidate the coastal upwelling ecosystems. Not enough is known about the structure and functioning of upwelling regions as ecological units and about their natural boundaries. We do know, however, that these boundaries are formed and/or maintained by related circulation patterns. Programmes like the 'World Ocean Circulation Experiment' (WOCE), the 'Joint Global Ocean Flux Studies' (JGOFS), and 'Global Ocean Ecosystem Dynamics' (GLOBEC) extended the existing database to the basin scale. Other programmes, such as 'European Station for Time-series in the Ocean, Canary Islands' (ESTOC) and 'Canary Azores Gibraltar Observations' (CANIGO) focus their efforts on interactions between EBCs and the gyre circulation. This concerns not only the availability of interdisciplinary data sets in adapted formats but also the crucial role of the EBCregimes for the description of climatic tendencies on the global scale.

Inter-annual variations in the upwelling area off Northwest Africa should be studied more intensively, maybe in the framework of GLOBEC or CLIVAR (study of climate variability and predictability). Related questions, which should be addressed by research activities planned for the near future, could be: which consequences of El Niño-like years can be expected for the ecosystem 'coastal upwelling' and what happens with the fishery during relaxed upwelling years off NW-Africa? What is the corresponding response of phyto- and zooplankton to drastic anomalies in the 'remote forcing'? How does such an upwelling regime react to the expected 'global warming', which is predicted to occur on the scale of centuries?

\section{Acknowledgements}

The EU funded project ENVIFISH (environment and fishery, IC-18-CT98-0329), which is still running in the coastal area of the Southwest African coast, initiated this study for comparison. In addition, we wish to thank the two reviewers for constructive recommendations and serious hints as well as colleagues of the group around Prof. G. Siedler of the Institute of Marine Research in Kiel. He continuously supported discussions between 'blue oceanographers' and sea-going 'shelf sea investigators', especially across the 'wall' between the former East- and West Germany. 


\section{REFERENCES}

Ajao, E.A., Houghton, R.W., 1998. Coastal ocean of equatorial West Africa from $10^{\circ} \mathrm{N}$ to $10^{\circ} \mathrm{S}$, coastal segment $(17, \mathrm{E})$. In: Robinson, A.R., Brink, K.H. (Eds.), The Sea. John Wiley \& Sons Inc., New York, pp. 605-631.

Barton, E.D., 1973. Upwelling off the coast of Northwest Africa. Ph.D. Thesis, University of Liverpool, Liverpool.

Barton, E.D., 1989. The poleward undercurrent on the eastern boundary of the subtropical North Atlantic. In: Neshyba, S.J., Mooers, C.N.K., Smith, R.L., Barber, R.T. (Eds.), Coastal and Estuarine Studies formerly Lecture Notes on Coastal and Estuarine Studies, 34 Poleward Flows Along Eastern Ocean Boundaries. Springer, New York, pp. 82-92.

Barton, E.D., 1998. Eastern boundary of the North Atlantic: Northwest Africa and Iberia. In: Robinson, A.R., Brink, K.H. (Eds.), The Sea. John Wiley \& Sons Inc., New York, pp. 633-657.

Barton, E.D., Huyer, A., Smith, R.L., 1977. Temporal variation observed in the hydrographic regime near Cabo Corveiro in the Northwest African upwelling region, February to April 1974. Deep-Sea Res. 24, 7-23.

Berger, W.H., Smetaczek, V., Wefer, G., 1989. Productivity of the ocean present and past. Dahlem Workshop Reports, John Wiley and Sons, New York.

Bleck, R., 1978. Simulations of coastal upwelling frontogenesis with an isopycnic coordinate model. J. Geophys. Res. 83, 6163-6171.

Blumsack, S.L., 1972. The transverse circulation near a coast. J. Phys. Oceanogr. 2, 34-40.

Bower, A.S., 1996. Update on 'A Mediterranean Undercurrent Seeding Experiment' (AMUSE). International WOCE Newsletter 24, 28-30.

Bray, N.A., 1982. Seasonal variability in the intermediate waters of the eastern North Atlantic. J. Phys. Oceanogr. 12, 972-983.

Brenning, U., 1985. Structure and development of Calanoid populations (Crustacea, Copepoda) in the upwelling regions off North and South West Africa. Beitr. Meereskunde 52, 3-33.

Brink, K.H., 1983. The near-surface dynamics of coastal upwelling. Prog. Oceanog. 12, 223-257.

Bubnov, V.A., Egorikhin, V.B., Matveeva, Z.N., Navrotskaya, S.E., Filippov, D.I., 1979, Graphical presentation of the USSR oceanographic observations in the tropical Atlantic during GATE (June to September,1974). Technical Report 79-1 of the University of Miami, Miami.

Catewicz, Z., Hagen, E., 1989. Further evidence for CSWs off Northwest Africa. Beitr. Meereskunde 59, 81-82.

Charney, J.G., 1955. The generation of oceanic currents by wind. J. Mar. Res. 14, 477-498.

Colin, C., 1988. Coastal upwelling events in front of the Ivory Coast during the FOCAL program. Oceanol. Acta 11, 125-138.

Crepon, M., Richez, C., Chartier, M., 1984. Effects of coastline geometry on upwelling. J. Phys. Oceanogr. 14, 1365-1382.

Cushing, D.H., 1982. Climate and fisheries. Academic Press, London.

Csanady, G.T., 1971. On the equilibrium of the thermocline in a shore zone. J. Phys, Oceanogr. 1, 263-270.
Delecluse, P., 1983. Coastal effects on upwelling. In: Nihoul, J.C.J. (Ed.), Hydrodynamics of the Equatorial Ocean. Elsevier, Amersterdam, pp. 259-279.

Demin, Y.L., Hagen, E., Gurina, A.M., 1981. Large-scale currents in the upper layer of the Canary upwelling area in summer. Oceanology 21, 613-618.

Deutsches Hydrographisches Institut, 1956. Monatskarten für den Nordatlantischen Ozean. Hamburg, No. 2420.

Ekman, V.W., 1905. On the influence of the earth's rotation on ocean currents. Ark. Mat. Astron. Fys. 2, 1-52.

Emery, W.J., Lee, W., Magaard, L., 1984. Geographic and seasonal distribution of Brunt-Väisälä frequency and Rossby radii in the North Pacific and North Atlantic. J. Phys. Oceanogr. 14, 294-317.

Fennel, W., 1992. Responses of a coastal ocean. Trends in Phys. Oceanography 1, 163-179.

Frouin, R., Fiuza, A.F.G., Ambar, I.L., 1990. Observations of a poleward surface current off the coasts of Portugal and Spain during winter. J. Geophys. Res. 95, 691-697.

Garvine, R.W., 1973. The effect of bathymetry on coastal upwelling of homogeneous water. J. Phys. Oceanogr. 3, 47-56.

Gill, A.E., Clarke, A.J., 1974. Wind-induced upwelling, coastal currents and sea-level changes. Deep-Sea Res. 21, 325-345.

Gillbricht, M., 1977. Phytoplankton distribution in the upwelling area off NW Africa. Helgoländer wiss. Meeresunters 29, 417-438.

Grötzner, A., Latif, M., Timmermann, A., Voss, R., 1998. Internal to decadal predictability in a coupled ocean-atmosphere general circulation model. Max-Planck-Institut für Meteorologie, Rep. 262, $1-32$.

Hagen, E., 1977. Zur Problematik mesoskaler Verwirbelungen in den Schelfgebieten des küstennahen Wasserauftriebs. Beitr. Meereskunde 39, 61-87.

Hagen, E., 1981. Mesoscale upwelling variations off the West African coast. In: Richardson F.A. (Ed.), Coastal and Estuarine Sciences, Vol. I, Coastal Upwelling. AGU, Washington DC, pp. 72-78.

Hagen, E., Kaiser, W., 1976. Untersuchungen zur raum-zeitlichen Struktur ozeanologischer Felder im Rahmen der mesoskalen Auftriebsdynamik, speziell für das Schelfgebiet vor Cap Blanc. Geod. Geophy.Veröff. R4, 19.

Hagen, E., Mittelstaedt, E., Feistel, R., Klein, H., 1994. Hydrographische Untersuchungen im Ostrandstromsystem vor Portugal und Marokko1991-1992 Berichte des Bundesamtes für Seeschiffahrt und Hydrographie 2.

Hagen, E., Schemainda, R., 1984. Der Guineadom im ostatlantischen Stromsystem. Beitr. Meereskunde 51, 5-27.

Hagen, E., Schemainda, R., 1987. On the annual distribution of South Atlantic Central Water (SACW) along a section off Cape Blanc, Northwest Africa. Oceanol. Acta, Special 19, 61-70.

Hagen, E., Schemainda, R., 1989. Mittlere und jahreszeitliche Strukturen im Unterstrom (UUC) des Auftriebsgebietes vor Nordwestafrika. Beitr. Meereskunde 59, 19-45.

Hagen, E., Schmager, G., 1991. On mid-latitude air pressure variations and related SSTA fluctuations in the tropical/ subtropical Northern Atlantic from 1957 to 1974. Z. Meteorol. 41, 176-190. 
Hagen, E., Zülicke, C., Feistel, R., 1996. Near-surface structures in the Cape Ghir filament off Morocco. Oceanol. Acta 19, 577-598.

Hidaka, K., 1954. A contribution to the theory of upwelling and coastal currents. Transactions, American Geophysical Union 35, 431-444.

Holloway, G., Brink, K., Haidvogel, D., 1989. Topographic stress in coastal circulation dynamics. In: Neshyba, S.J., Mooers, C.N.K., Smith, R.L., Barber, R.T. (Eds.), Coastal and estuarine Studies (formerly lecture notes on coastal and estuarine studies), 34 Poleward Flows Along Eastern Ocean Boundaries. Springer, New York, pp. 315-330.

Hsueh, Y., Cushman-Roisin, B., 1983. On the formation of surface to bottom fronts over steep topography. J. Geophys. Res. 88, 743-750.

Hughes, P., Barton, E.D., 1974. Stratification and water mass structure in the upwelling area off Northwest Africa in April/May 1969. Deep-Sea Res. 21, 611-628.

Huthnance, J.M., 1975. On trapped waves over a continental shelf. J. Fluid Mech. 69, 689-704.

Huthnance, J.M., 1978. On coastal trapped waves Analysis and numerical calculation by inverse iteration. J. Phys. Oceanogr. 8 , 74-92.

Isemer, H.J., Hasse, L., 1987. The Bunker climate atlas of the North Atlantic Ocean, Air-Sea Interactions Vol.2. Springer, New York.

John, H.C., Mittelstaedt, E., Schulz, K., 1998. The boundary circulation along the European continental slope as transport vehicle fot two calanid copepods in the Bay of Biscay. Oceanol. Acta 21, 307-318.

John, H.C., Zelck, C., 1997. Features, boundaries and connecting mechanisms of the Mauritanian Province exemplified by oceanic fish larvae. Helgoländer Meeresuntersuchungen 51, 213-240.

Keunecke, K.H., Tomczak, M., 1976. Evidence of increased turbulent mixing in the coastal jet of the NW-African upwelling region. Meteor Forsch.-Ergebnisse, A 17, 88-98.

Klein, B., Siedler, G., 1989. On the origin of the Azores Current. J. Geophys. Res. 94, 6159-6168.

Knoll, M., Zenk, W., Bauer, E., 1982. Some XBT-observations on the thermal structure of the 'Warmwassersphäre' in equatorial and lower latitudes of the eastern Atlantic. Deutsch. Hydrogr. Z. 35, 73-81.

Krauss, W., Wübber, C., 1982. Response of the North Atlantic on annual wind variations along the eastern coast. Deep-Sea Res. 29, 851-868.

Latif, M., Barnett, T.P., 1994. Causes of decadal climate variability over the North Pacific and North America. Science 266, 634-637.

Lentz, S.J., 1992. The surface boundary layer in coastal upwelling regions. J. Phys. Oceanogr. 22, 1517-1539.

Lighthill, M.J., 1969. Dynamic response of the Indian Ocean to the onset of the southwest monsoon, Philos. Trans. R. Soc, London A265, pp. 45-92.

Lippert, A., Käse, R.H., 1985. Stochastic wind forcing of baroclinic Rossby waves in the presence of a meridional boundary. J. Phys. Oceanogr. 15, 184-194.

Lozier, M.S., Owens, W.B., Curry, R.G., 1995. The climatology of the North Atlantic. Prog. Oceanogr. 36, 1-44.
Luyten, J.R., Pedlowsky, J., Stommel, H., 1983. The ventilated thermocline. J. Phys. Oceanogr. 13, 292-309.

Margalef, R., 1978. Phytoplankton communities in upwelling areas. The example of NW-Africa. Oecologia Aquatica 3, 97-132.

May, W., Bengtsson , L., 1996. On the impact of the El Niño/ Southern Oscillation phenomenon on the atmospheric circulation in the northern hemisphere extratropics. Max-Planck-Institut für Meteorologie Rep. No. 224, 1-61.

McCreary, J.P., 1976. Eastern tropical ocean response to changing wind systems with application to El Niño. J. Phys. Oceanogr. 6, 632-645.

McCreary, J.P., 1981. A linear stratified ocean model of the coastal undercurrent, Philos. Trans. R. Soc, London, A 302, pp. 385-413.

Meincke, J., Siedler, G., Zenk, W., 1975. Some current observations near the continental slope off Portugal. Meteor Forsch.-Ergebnisse, A $16,15-22$.

Michelchen, N., 1981. Estimates of large-scale atmospheric pressure variations in the upwelling area off Northwest Africa. In: Richards, F.A. (Ed.), Coastal Upwelling, Coastal and Estuarine Science 1. AGU, Washington DC, pp. 17-20.

Michelchen, N., 1989. Auswirkungen globaler and regionaler Anomalien im System Ozean-Atmosphäre auf den küstennahen Kaltwasserauftrieb im zentralen Ostatlantik. Geod. Geoph. Veröff. R4, 44.

Minas, H.J., Codispoti, L.A., Dugdale, R.C., 1982. Nutrients and primary production in the upwelling region off Northwest Africa. Rapp. P.-v. Réun. Cons. int. Explor. Mer 180, 148-183.

Mittelstaedt, E., 1976. On the currents along the Northwest African coast south of $22^{\circ}$ N. Dt. Hydrogr. Z. 29, 97-117.

Mittelstaedt, E., 1989. The subsurface circulation along the Moroccan slope. In: Neshyba, S.J., Mooers, C.N.K., Smith, R.L., Barber, R.T. (Eds.), Coastal and Estuarine Studies (formerly Lecture notes on coastal and estuarine studies), 34 Poleward Flows Along Eastern Ocean Boundaries. Springer, New York, pp. 96-108.

Mittelstaedt, E., 1991. The ocean boundary along the northwest African coast Circulation and oceanographic properties at the sea surface. Prog. Oceanogr. 26, 307-355.

Mittelstaedt, E., Haman, I., 1981. The coastal circulation off Mauritania. Dt. Hydrogr. Z. 34, 81-118.

Mittelstaedt, E., Pillsbury, D., Smith, R.L., 1975. Flow patterns in the northwest African upwelling area. Dtsch. Hydrogr. Z. 28, 145-167.

Müller, T.J., Siedler, G., 1992. Multi-year current time series in the eastern North Atlantic Ocean. J. Mar. Res. 50, 63-98.

Mysak, L.A., 1980. Recent advances in shelf wave dynamics. Rev. Geophys. Space Phys. 18, 211-241.

Nehring, D., Schemainda, R., Schulz, S., 1975. Beiträge der DDR zur Erforschung der küstennahen Wasserauftriebsprozesse im Ostteil des nördlichen Zentralatlantiks. Vb, das ozeanographische Beobachtungsmaterial des Reiseabschnittes vom 4.2. bis 18.4.1973. Geod. Geoph.Veröff. R4, 15.

Nykjaer, L., Van Camp, L., 1994. Seasonal and interannual variability of coastal upwelling along northwest Africa and Portugal from 1981 to 1991. J. Geophys. Res. 99, 14197-14207. 
O’Brien, J.J., Adamec, D., Moore, D.W., 1978. A simple model of upwelling in the Gulf of Guinea. Geophysical Research Letters 5, 641-644.

O'Brien, J.J., Hurlburt, H.E., 1972. A numerical model of coastal upwelling. J. Phys. Oceanogr. 2, 14-26.

Philander, S.G.H., 1980. The Equatorial Undercurrent revisited. Ann. Rev. Earth Planet. Sci. 8, 191-204.

Philander, S.G.H., 1981. The response of equatorial oceans to a relaxation of the trade winds. J. Phys, Oceanogr. 11, 176-189.

Philander, S.G.H., Yoon, J.H., 1982. Eastern boundary currents and coastal upwelling. J. Phys. Oceanogr. 12, 862-879.

Postel, L., Arndt, E.A., Brenning, U., 1995. Rostock zooplankton studies off West Africa. Helgoländer Meeresuntersuchungen 49, 829-847.

Postel, L., Zahn, W., 1987. Einfluß des Nouakchott-Canyons (Mauretanien) auf ozeanologische Feldverteilungen im März19841. Einführung und Meßprogramm. Beitr. Meereskunde 57, 45-50.

Rogers, J.C., 1984. The association between the North Atlantic Oscillation and the Southern Oscillation in the northern hemisphere. Monthly Weather Review 112, 1999-2015.

Schemainda, R., Nehring, D., Schulz, S., 1975. Ozeanologische Untersuchungen zum Produktionspotential der nordwestafrikanischen Wasserauftriebsregion 1970-1973. Geod. Geophys. Veröff. R 4 16, $88 \mathrm{~S}$.

Schwartzlose, R.A., Alheit, J., Bakun, A., Baumgartner, T., Cloete, R., Crawford, R.J.M., Fletcher, W.J., Green-Ruiz, Y., Hagen, E., Kawasaki, T., Lluch-Belda, D., Lluch-Cota, S.E., MacCall, A.D., Matsuura, Y., Nevarez-Martinez, M.O., Parrish, R.H., Roy, C., Serra, R., Shust, K.V., Ward, M.N., Zuzunaga, J.Z., 1999. Worldwide large-scale fluctuations of sardine and anchovy populations. South Afr. J. Mar. Sci. 21, 289-347.

Sedykh, K.A., 1978. The coastal upwelling off the Northwest Africa. International Council for the Exploration of the Sea, Hydrographic Committee, C. E./ C 12.

Servain, J., Picaut, J., Merle, J., 1982. Evidence of remote forcing in the equatorial Atlantic Ocean. J. Phys. Oceanogr. 12, 457-463.

Siedler, G., Finke, M., 1993. Long-period transport changes in the eastern North Atlantic and their simulation by propagating waves. J. Geophys. Res. 98, 2393-2406.

Siedler, G., Zangenberg, N., Onken, R., Morlière, A., 1992. Seasonal changes in the tropical Atlantic circulation observation and simulation of the Guinea Dome. J. Geophys. Res. 97, 703-715.

Smith, R.L., 1995. On the process of upwelling new observations and understanding. In: Hagen, E., da Silva, J. (Eds.), Dynamics of upwelling in the ICES area, ICES Cooperative Research Report, 206, pp. 15-33.

Speth, P., Köhne, A., 1983. The relationship between sea surface temperatures and wind off Northwest Africa and Portugal. Oceanogr. trop. $18,69-80$.

Stöhr, S., Hagen, E., John, H.C., Mittelstaedt, E., Schulz, K., Vanicek, M., Weikert, H., 1997. Poleward plankton transport along the Moroccan and Iberian continental slope. Berichte der Biologischen Anstalt Helgoland 12, 1-53.
Stramma, L., 1984. Geostrophic transport in the warm water sphere of the eastern subtropical North Atlantic. J. Mar. Res. 42, 537-558.

Suginohara, N., 1982. Coastal upwelling onshore-offshore circulation, equatorial coastal jet and poleward undercurrent over a continental shelf-slope. J. Phys. Oceanogr. 12, 272-284.

Suginohara, N., Kitamura, Y., 1984. Long-term coastal upwelling over a continental shelf-slope. J. Phys. Oceanogr. 14, 1095-1104.

Sverdrup, H.U., Johnson, M.W., Fleming, R.H., 1942. The oceans their physics, chemistry, and general biology. Prentice-Hall, Inc., New York.

Tomczak, M., 1977. Continuous measurement of near-surface temperature and salinity in the NW African upwelling region between Canary Islands and Cap Vert during the winter of 1971-1972. Deep Sea Res. 24, 1103-1119.

Tomczak, M., 1984. Ausbreitung und Vermischung der Zentralwassermassen in den Tropengebieten der Ozeane, 1. Atlantischer Ozean. Oceanol. Acta 7, 145-158.

Tomczak, M., Godfrey, J.S., 1994. Regional oceanography: an introduction. Pergamon, Oxford.

Tomczak, M., Käse, R., 1974. A linear theory of stationary coastal upwelling in a continuously stratified ocean with an unstratified shelf area. J. Mar. Res. 32, 365-376.

Van Camp, L., Nykjaer, L., Mittelstaedt, E., Schlittenhardt, P., 1991. Upwelling and boundary circulation off Northwest Africa as depicted by infrared and visible satellite observations. Prog. Oceanogr. 26, 357-402.

Voituriez, B., 1981. Equatorial upwelling in the Eastern Atlantic problems and paradoxes. In: Richards, F.A. (Ed.), Coastal Upwelling, Coastal and Estuarine Science 1. AGU, Location, pp. 95-106.

Ward, M.N., Hoskins, B.J., 1996. Near-surface wind over the global ocean1949-1988. Journal of Climate 9, 1877-1895.

Wefer, G., Fischer, G., 1993. Seasonal patterns of vertical particle flux in equatorial and coastal upwelling areas of the eastern Atlantic. Deep-Sea Res. 40, 1613-1645.

Willenbrink, E., 1982. Wassermassenanalyse im tropischen und subtropischen Nordostatlantik. Berichte aus dem Institut für Meereskunde Kiel 96, 1-72.

Wolf, G., Kaiser, W., 1978. Über den Jahreszyklus der T-SEigenschaften quasipermanenter Wasserarten und Variationen produktionsbiologischer Parameter auf dem Schelf vor Cap Blanc. Geod. Geophy. Veröff. R4 24, 1-81.

Wooster, W.S., Bakun, A., McLain, D.R., 1976. The seasonal upwelling cycle along the eastern boundary of the North Atlantic. J. Mar. Res. 34, 131-141.

Yoshida, K., 1955. Coastal upwelling off the California coast. Records Oceanogr. Works Japan 2, 8-20.

Zenk, W., 1980. The sub-Mediterranean undercurrent. Deep-Sea Res. 27, 97-98.

Zenk, W., Armi, L., 1990. The complex spreading pattern of Mediterranean water off the Portuguese continental slope. Deep-Sea Res. 37, 1805-1823.

Zenk, W., Klein, B., Schröder, M., 1991. Cape Verde Frontal Zone. Deep Sea Res. 38, Suppl. 1, 505-530. 